UDC 577.151.6 : 612.115

\title{
STUDY OF THE SITES OF PLASMINOGEN MOLECULE WHICH ARE RESPONSIBLE FOR INHIBITORY EFFECT OF LYS-PLASMINOGEN ON PLATELET AGGREGATION
}

\author{
Y. M. ROKA-MOYA, D. D. ZHERNOSSEKOV, E. I. YUSOVA, \\ L. G. KAPUSTIANENKO, T. V. GRINENKO
}

Palladin Institute of Biochemistry, National Academy of Sciences of Ukraine, Kyiv; e-mail: chemikdd@mail.ru

\begin{abstract}
Plasminogen/plasmin system is involved in such important processes as thrombosis, inflammation and cancer. Plasmin and plasminogen mediate their action through plasminogen-binding proteins on the cell surface. Lys-plasminogen, but not Glu-plasminogen, shows inhibitory effect on platelet aggregation induced by ADP, collagen and thrombin in preparations of both: platelet-rich plasma and washed platelets. We have shown that the kringle domains of Lys-plasminogen mediate interaction of this proenzyme with plateletsurface proteins. The aim of the work is to study the role of certain kringle domains in the inhibitory effect of Lys-plasminogen and to determine possible plasminogen-binding proteins on the platelet surface. All studied plasminogen fragments (K1-3, K4 and K5) abolished the inhibitory effect of Lys-plasminogen on platelet aggregation. We observed that K5 was more effective than K1-3 and K4. Biotin-labeled Lys-plasminogen, Gluplasminogen and plasminogen fragment K1-3 possessed the highest affinity for actin, whereas the binding of biotin-labeled mini-plasminogen and K4 to actin was negligible. We have suggested that inhibitory effect of Lys-plasminogen is due to the interaction of kringle domains of this proenzyme with membrane-bound proteins which are exposed on the platelet surface during activation and are involved in thrombus formation.
\end{abstract}

Key words: plasminogen kringles, platelet aggregation, platelet plasminogen receptors, Lys-plasminogen, actin.

$\mathrm{P}$ lasminogen is the pro-enzyme of plasmin, the main enzyme of fibrinolysis. However, plasminogen is also able to bind to cell surface and provide many important reactions including proteolytic activity, cell migration and signaling. So, plasminogen can play a certain role in such important biological processes as inflammation, thrombosis and cancer $[1,2]$. The circulating form of plasminogen is a $92 \mathrm{kDa}$ single-chain zymogen, composed of 791 amino acids and divided into seven structural domains: N-terminal peptide domain, five kringle domains and $\mathrm{C}$-terminal serine protease domain. Four of five kringle domains (K1, K2, K4 and K5) contain lysine-binding sites (LBS), which mediate plasminogen interaction with fibrin clots and cellsurface receptors. K3-LBS does not bind lysine. It was found that K1-LBS is the only LBS for ligand binding in circulating plasminogen, whereas all other LBS are blocked as they are engaged in intramolecular interactions [3]. Compact form of circulating plasminogen is provided by inter-domain interactions between the N-terminal peptide domain and $\mathrm{K} 5$ and between $\mathrm{K} 3$ and $\mathrm{K} 4$ organized in a spiral-type domain conformation [4]. Cleavage of the $\mathrm{N}$-terminal peptide by plasmin yields a truncated form known as Lys-plasminogen, which is present in an open conformation. Lys-form of plasminogen has some functional peculiarities. It is more readily converted into plasmin [5]. Under physiological conditions Lys-plasminogen is not present in circulating blood [6]. However, on the cell surface Lysplasminogen is the predominant substrate for plasminogen activators [7]. Besides, we have found that Lys-plasminogen but not its Glu-form inhibits the thrombin- and collagen-induced aggregation in the preparation of washed platelets and ADP-induced aggregation in preparations of platelet rich plasma. As it is known, there are many proteins which are exposed on the platelet surface during activation and play an important role in platelet aggregation. Some of these proteins are able to interact with plasminogen $[8,9]$. It was shown that 6 -aminohexanoic acid abolishes the inhibitory effect of Lys-plasminogen that is compatible with the participation of LBS of 
kringle domains in the inhibitory process [10]. The aim of the present work is to study the role of certain kringle domains of plasminogen molecule in the inhibitory effect of Lys-plasminogen and to determine possible plasminogen-binding proteins on the platelet surface.

\section{Materials and Methods}

Human platelets were isolated from blood of healthy volunteers $(n=9)$. Citrate-dextrose solution was used as an anticoagulant and platelets were washed as previously described [10]. Human Glu-plasminogen was purified from fresh donor plasma with sodium citrate as an anticoagulant and Lys-plasminogen was isolated from Cohn fraction II-III. Lysine-sepharose chromatography was used in both cases [11]. Mini-plasminogen and plasminogen kringles K1-3 and K4 were obtained according to [12] by elastase hydrolyses of plasminogen. Fragment K5 was obtained by the limited proteolysis of mini-plasminogen with pepsin. $\mathrm{K} 5$ isolation was carried out by combination of ion-exchange chromatography on DEAE-sephadex A-25 and gel-chromatography on sephadex G-75 $[13,14]$. The obtained plasminogen forms, kringles K1-3, K4 and K5 were homogeneous according to electrophoresis data in PAAG [15]. All preparations of plasminogen had no spontaneous plasmin activity.

The influence of plasminogen fragments (K1-3, $\mathrm{K} 4, \mathrm{~K} 5$ ) on the inhibitory effect of Lys-plasminogen has been studied. Platelet aggregation was measured in an aggregometer (SOLAR AT-02, Belorussia). All assays were performed within 60-180 minutes of platelet collection. The preparation of washed platelets $(350,000$ cells $/ \mu \mathrm{l})$ was set in aggregometer cuvette, then platelet suspension was preincubated with plasminogen fragments (final concentration $0.12-1.2 \mu \mathrm{M}$ ) for one minute at $37^{\circ} \mathrm{C}$ under stirring, then $1.2 \mu \mathrm{M}$ Lys-plasminogen was added to the reaction mixture. After 3 minute incubation the platelet aggregation was stimulated with thrombin (final concentration $1 \mathrm{NIH}$ unit $/ \mathrm{ml}$ ). The preparation of washed platelets stimulated by thrombin was used as a control. The level of control platelet aggregation (the range from 50 to $70 \%$ ) was taken as $100 \%$ value in the histograms.

Biotinylation of plasminogen and its fragments was carried out as described in [16]. The binding of biotin-labeled Glu-, Lys-, mini-plasminogen (Val 442-Pg) and plasminogen kringles K1-3 and K4 to immobilized actin has been studied according to the following procedure. Microtiter plate wells (Nunc, Denmark) were coated with $100 \mu 1$ of $10 \mu \mathrm{g} / \mathrm{ml}$ actin in PBS overnight at $4{ }^{\circ} \mathrm{C}$ and then washed five times with $0.1 \mathrm{M}$ sodium phosphate buffer (PBS), $\mathrm{pH} 7.4$, containing $0.02 \%$ tween-20. Wells were blocked with $2 \%$ BSA in PBS for one hour at $37^{\circ} \mathrm{C}$. Biotinylated Glu-, Lys-, mini-plasminogen and K1-3 or K4 were added to wells. After two hours of incubation at $37{ }^{\circ} \mathrm{C}$ the wells were washed and phosphatase-labeled avidin $(100 \mu 1$ of $0.02 \mathrm{ng} / \mathrm{ml}$ avidin in PBS) was added to the wells. After one hour of incubation at $37{ }^{\circ} \mathrm{C}$ the wells were washed and pnitrophenyl phosphate $(100 \mu \mathrm{l}$ of $1 \mathrm{mg} / \mathrm{ml}$ in $10 \%$ diethanolamine buffer, $\mathrm{pH} 9.8$ ) was added. The alcaline phosphatase-dependent conversion of the substrate was read at $405 \mathrm{~nm}$ after 45 minute incubation (Multiscan EX Thermo, China). Experimental data were statistically analyzed using software MS Excel and Agrometr 2.01.

Human plasma thrombin, porcine pancreas elastase, porcine stomach mucose pepsine and bovine muscle actin were purchased from Sigma (USA).

\section{Results and Discussion}

As shown in Fig.1-3 the inhibitory effect of Lys-plasminogen on thrombin-induced platelet aggregation is observed. In the presence of Lys-plasminogen the level of platelet aggregation is an average of two times lower. We have noticed that all studied plasminogen kringles (K1-3, K4 and K5) abolish the inhibitory effect of Lys-plasminogen on platelet aggregation at concentration $1.2 \mu \mathrm{M}$. However, we have observed that $\mathrm{K} 5$ is more effective than K1-3 and K4. The plasminogen kringle K5 added to the reaction mixture (washed platelets and $1.2 \mu \mathrm{M}$ Lys-plasminogen) even at concentration $0.12 \mu \mathrm{M}$ recovers platelet aggregation to $90 \%$, whereas K1-3 and $\mathrm{K} 4$ at this concentration reach only near $60 \%$ as compared with control aggregation level (Fig. 1-3). Besides, we have observed the tendency of slight stimulation of platelet aggregation in the presence of $\mathrm{K} 5$ at concentration $1.2 \mu \mathrm{M}$ (Fig. 3).

We have also made an attempt to answer the question concerning affinity of plasminogen forms (Glu- or Lys-plasminogen) and plasminogen fragments (K1-3, K4 or mini-plasminogen, which contains $\mathrm{K} 5$ and serine protease domain) for actin. Our results showed that Lys-plasminogen possessed the highest affinity for actin (Fig. 4, A). Glu-plasminogen and plasminogen fragment $\mathrm{K} 1-3$ had similar $\mathrm{IC}_{50}$ value, 113 and $117 \mathrm{nM}$, respectively. The binding of 


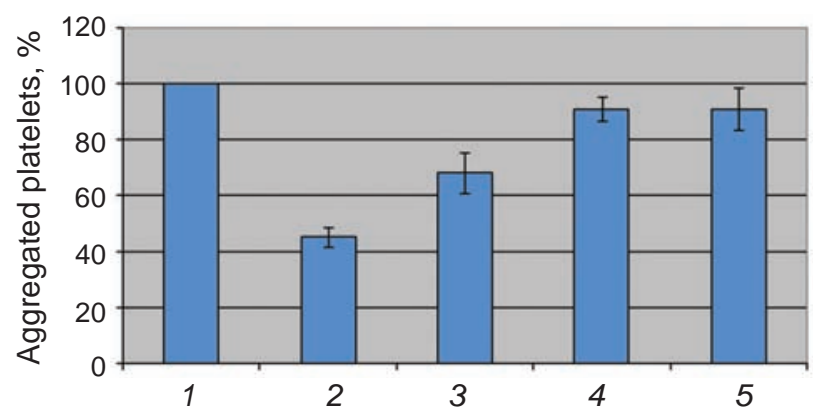

Fig. 1. The influence of plasminogen fragment K1-3 on the inhibitory effect of Lys-plasminogen on thrombin-induced platelet aggregation: 1 - control; 2 - 1.2 $\mu M$ LysPg; $3-0.12 \mu M$ K1-3 + 1.2 $\mu M$ LysPg; $4-0.6 \mu M$ K1-3 + $1.2 \mu M$ LysPg; 5 - $1.2 \mu M$ K1-3 + $1.2 \mu M \mathrm{LysPg}$. Here and below in Fig. 2-4: mean of three experiments (bars, $S D$ )

mini-plasminogen and $\mathrm{K} 4$ to actin was negligible. To precise $\mathrm{IC}_{50}$ value in case of Lys-plasminogen, the range of lower concentration was used (to $30 \mathrm{nM}$ ). According to the obtained data, $\mathrm{IC}_{50}$ value in this case was $1.8 \mathrm{nM}$ (Fig. 4, B).

The observed effect of plasminogen kringles on the inhibition of platelet aggregation by Lys-plasminogen lets us conclude that LBS of plasminogen kringles provide the plasminogen binding to the adhesive proteins of platelet surface. There are several candidates for the role of Lys-plasminogen receptors on the surface of activated platelets $[17,18]$. These proteins are secreted from $\alpha$-granules and remain bound to platelet surface. One of them is thrombospondin, its receptor CD47 is highly expressed on platelets [19]. Thrombospondin was proposed to

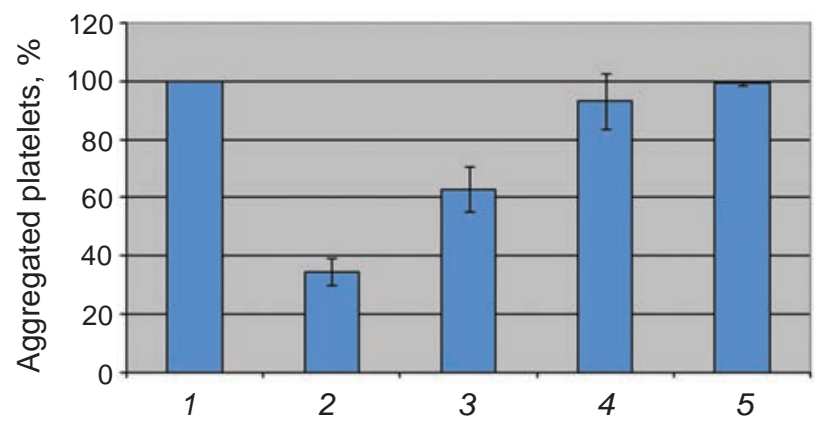

Fig. 2. The influence of plasminogen fragment $\mathrm{K} 4$ on the inhibitory effect of Lys-plasminogen on thrombin-induced platelet aggregation: 1 - control; 2 - $1.2 \mu M$ LysPg; $3-0.12 \mu M K 4+1.2 \mu M L y s P g$; $4-0.6 \mu M K 4+1.2 \mu M$ LysPg; $5-1.2 \mu M K 4+$ $1.2 \mu \mathrm{M} \mathrm{LysPg}$ bridge platelets via binding to fibrinogen bound to the platelet integrin $\alpha \operatorname{IIb} \beta 3$ or by binding directly to this integrin [20]. At the same time some of thrombospondin repeats, TSR1 and TSR2, are considered as the binding sites to plasminogen [8]. Thrombospondin has two binding sites for fibrinogen, one of which (TSR1) coincides with plasminogen binding site. It was suggested that the binding site of plasminogen to thrombospondin is located within the kringle 5 domain [21]. It was interesting to note that Lys-plasminogen binds to thrombospondin to a greater extent than Glu-form. At saturation thrombospondin bound approximately 3 times as much of Lys-plasminogen than Glu-plasminogen. So, we can suggest that in our experiments Lys-plasminogen can probably impede the effective binding of thrombospondin to fibrinogen and, as a result, the platelet aggregation can be less effective (see Fig. 5). The peculiarity of kringle 5 which we have shown here is in accordance with this suggestion. On the other hand, actin can also be considered as a possible candidate for plasminogen binding. It is known that actin is exposed on the platelet surface after thrombin-induced secretion [22]. Plasminogen is able to bind actin with high affinity [23]. As we can conclude from the obtained results the leading role in this interaction may belong to plasminogen fragment K1-3.

We cannot also strike off fibrinogen from the list of possible candidates for plasminogen binding. It is known that Glu-plasminogen does not bind to fibrinogen in solution, and Lys-plasminogen under these conditions shows little affinity [24]. As it was found before, fibrinogen adsorbed on the surface undergoes conformational changes and acquires

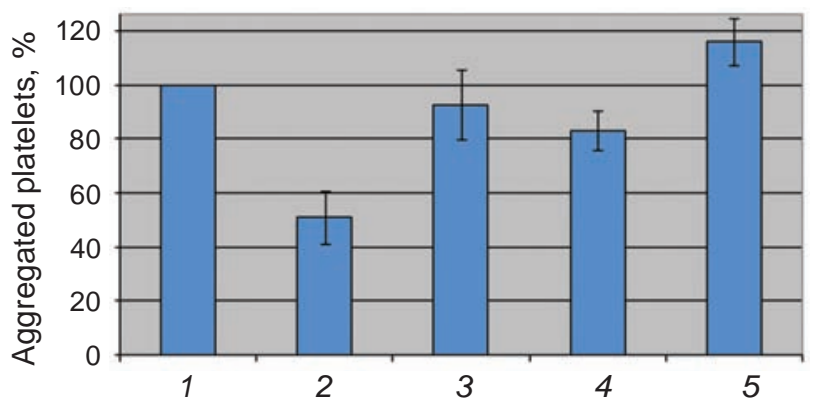

Fig. 3. The influence of plasminogen fragment K5 on the inhibitory effect of Lys-plasminogen on thrombin-induced platelet aggregation: 1 - control; 2 - 1.2 $\mu$ M LysPg; $3-0.12 \mu M$ K5 + 1.2 $\mu M$ LysPg; $4-0.6 \mu M K 5+1.2 \mu M$ LysPg; $5-1.2 \mu M K 5+$ $1.2 \mu M \mathrm{Lys} P g$ 
A

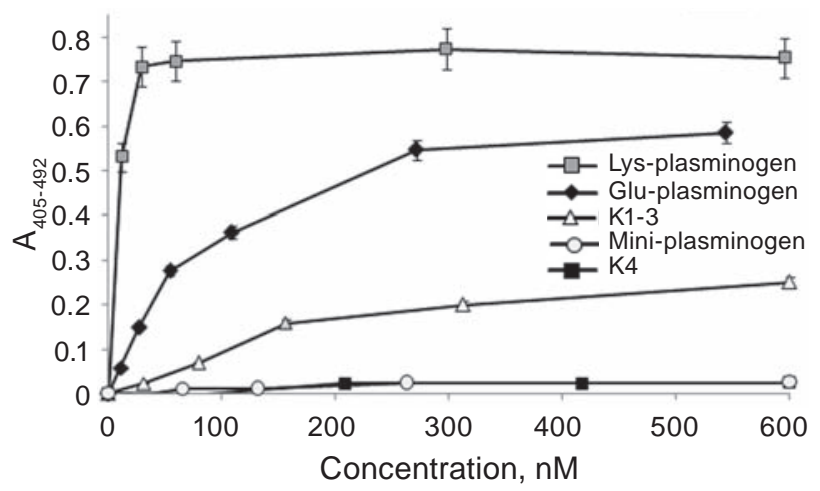

$B$

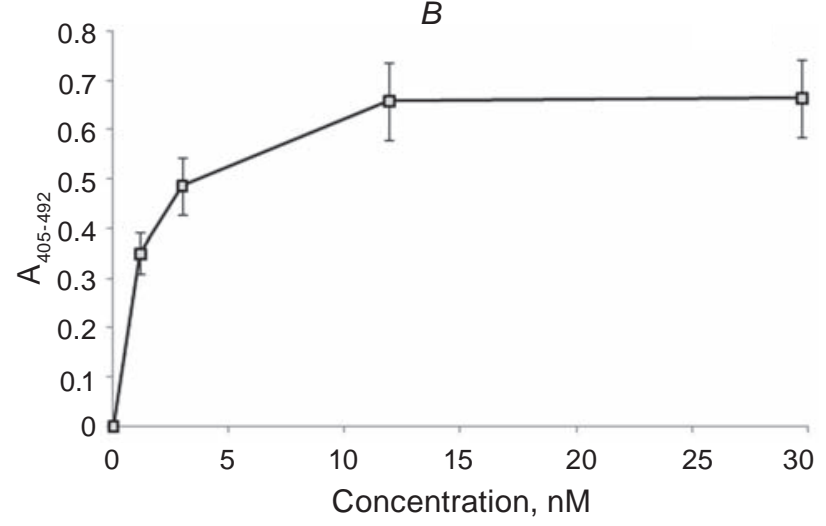

Fig. 4. The binding of biotin-labeled Glu-, Lys-, mini-plasminogen (Val 442-Pg) and plasminogen kringles K1-3 and K4 to actin (A), the binding of biotin-labeled Lys-plasminogen to actin (B)

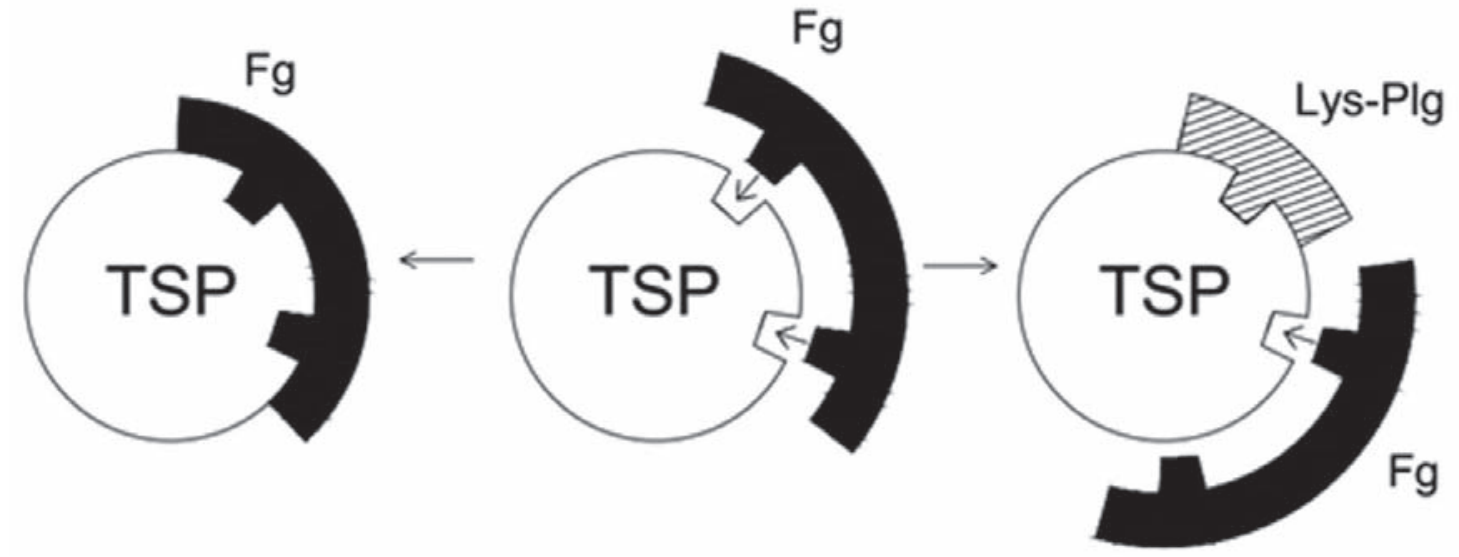

Fig. 5. Fibrinogen-thrombospondin interaction in the presence of Lys-plasminogen: Fg - fibrinogen, TSP thrombospondin, Lys-Plg - Lys-plasminogen

the properties of fibrin [25], which possesses good binding abilities to Lys-plasminogen [26]. There is also a possibility of immediate interaction of plasminogen with $\beta 2$-integrins on the platelet surface. Activated but not resting platelets are able to express $\beta 2$-integrins [27] and specific interaction between isolated $\mathrm{K} 4$ of plasminogen and $\alpha \mathrm{M} \beta 2$-integrin was identified in case of leucocytes [28]. The obtained data let us suggest that kringle 4 may play a certain role in the interaction of Lys-plasminogen with this integrin on the platelet surface. However, the role of $\alpha \mathrm{M} \beta 2$ in platelet adhesion or aggregation is still unknown.

So, the obtained effects of plasminogen kringles let us conclude that LBS of plasminogen kringles can interact with some adhesive proteins on the surface of activated platelets. This interaction may lead to the disturbance of protein-protein interaction which is the necessary condition for efficient platelet aggregation.

\section{ВИВЧЕННЯ САЙТІВ МОЛЕКУЛИ \\ ПЛАЗМІНОГЕНУ, ЩО \\ ЗАБЕЗПЕЧУЮТЬ ІНГІБУВАЛЬНИЙ \\ ВПЛИВ LyS-ПЛАЗМІНОГЕНУ НА АГРЕГАЦІЮ ТРОМБОЦИТІВ}

\section{Я. М. Рока-Мойя, Д. Д. Жерносєков, \\ О. І. Юсова, Л. Г. Капустяненко, \\ Т. В. Гриненко}

Інститут біохімії ім. О. В. Палладіна НАН України, Київ; e-mail: chemikdd@mail.ru

Плазміноген/плазмінова система залучена до таких важливих процесів як тромбоутворення, запалення та канцерогенез. Плазміноген та плазмін опосередковують свою дію через плазміногензв'язуючі протеїни, що розташовані на поверхні клітин. Lys-плазміноген, на відміну 
від Glu-форми, справляє інгібувальний вплив на агрегацію тромбоцитів, стимульовану ADP, колагеном та тромбіном в препаратах збагаченої тромбоцитами плазми та відмитих тромбоцитів. Ми показали, що кринглові домени плазміногену забезпечують взаємодію цієї молекули 3 поверхневими протеїнами тромбоцитів. Метою роботи було вивчення ролі окремих кринглових доменів у виявленні інгібувального впливу Lys-плазміногену на агрегацію тромбоцитів та визначення можливих плазміногензв'язуючих протеїнів на поверхні тромбоцитів. Усі фрагменти плазміногену (K1-3, K4 і K5), що були взяті для дослідження, знімали інгібувальний вплив Lys-плазміногену на агрегацію тромбоцитів. Показано, що ефект К 5 більш виражений порівняно з K1-3 та K4. Препарати біотинільованих Lysплазміногену, Glu-плазміногену та фрагмента К1-3 виявляли найбільшу афінність до актину, тоді як зв'язування біотинільованих мініплазміногену та K4 з актином було незначним. Ми припускаємо, що інгібувальний ефект Lysплазміногену є наслідком взаємодії кринглових доменів цього протеїну з мембранозв'язаними протеїнами, що експонуються на поверхні тромбоцита під час активації та залучаються до процесу тромбоутворення.

К л ю ч о в і с л о в а: крингли плазміногену, агрегація тромбоцитів, плазміногенові рецептори тромбоцитів, Lys-плазміноген, актин.

\section{ИЗУЧЕНИЕ САЙТОВ \\ МОЛЕКУЛЫ ПЛАЗМИНОГЕНА, ОБЕСПЕЧИВАЮЩИХ ИНГИБИРУЮЩИЙ ЭФФЕКТ LУS- ПЛАЗМИНОГЕНА НА АГРЕГАЦИЮ ТРОМБОЦИТОВ}

\section{Я. М. Рока-Мойя, Д. Д. Жерносеков, \\ Е. И. Юсова, Л. Г. Капустяненко, \\ T. В. Гриненко}

Институт биохимии им. А. В. Палладина НАН Украины, Киев; e-mail: chemikdd@mail.ru

Плазминоген/плазминовая система вовлечена в такие важные процессы как тромбообразование, воспаление и канцерогенез. Плазминоген и плазмин опосредуют свое действие через плазминогенсвязывающие протеины на поверхности клеток. Lys-плазминоген, в отли- чие от Glu-формы, оказывает ингибирующее влияние на агрегацию тромбоцитов, стимулированную ADP, коллагеном и тромбином в препаратах обогащенной тромбоцитами плазмы и отмытых тромбоцитов. Мы показали, что крингловые домены плазминогена обеспечивают взаимодействие этого проэнзима с поверхностными протеинами тромбоцитов. Целью настоящей работы было изучить роль определенных крингловых доменов в реализации ингибиторного эффекта Lys-плазминогена и определить возможные плазминогенсвязывающие протеины на поверхности тромбоцитов. Все исследуемые фрагменты плазминогена (K1-3, K4 и K5) снимали ингибирующее действие Lys-плазминогена на агрегацию тромбоцитов. Мы обнаружили, что К5 обладал более выраженным эффектом по сравнению с К1-3 и К4. Препараты биотинилированных протеинов Lys-плазминогена, Glu-плазминогена, и фрагмента K1-3 проявляли наибольшее сродство к актину, в то время как связывание биотинилированных мини-плазминогена и K4 с актином было незначительным. Мы предполагаем, что ингибиторный эффект Lys-плазминогена является следствием взаимодействия крингловых доменов этого протеина с мембраносвязанными протеинами, которые экспонируются на поверхности тромбоцита во время активации и вовлекаются в процесс тромбообразования.

К л ю че в ы е с л о в а: кринглы плазминогена, агрегация тромбоцитов, плазминогеновые рецепторы тромбоцитов, Lys-плазминоген, актин.

\section{References}

1. Godier A., Hunt B. J. Plasminogen receptors and their role in the pathogenesis of inflammatory, autoimmune and malignant disease. J. Thromb. Haemost. 2013;11(1):26-34.

2. Rijken D. C., Lijnen H. R. New insights into the molecular mechanisms of the fibrinolytic system. J. Thromb. Haemost. 2009;7(1):4-13.

3. Xue Y., Bodin C., Olsson K. Crystal structure of the native plasminogen reveals an activationresistant compact conformation. J. Thromb. Haemost. 2012;10(7):1385-1396

4. Marshall J. M., Brown A. J., Ponting C. P. Conformational studies of human plasminogen and plasminogen fragments: evidence for a novel third conformation of plasminogen. Biochem. 1994;33(12):3599-3606. 
5. Gong Y., Kim S.-O., Felez J., Grella D. K., Castellino F. J., Miles L .A. Conversion of Gluplasminogen to Lys-plasminogen is necessary for optimal stimulation of plasminogen activation on the endothelial cell surface. J. Biol. Chem. 2001;276(22):19078-19083.

6. Holvoet P., Lijnen H. R., Collen D. A monoclonal antibody specific for Lys-plasminogen. Application to the study of the activation pathways of plasminogen in vivo. J. Biol. Chem. 1985;260(22):12106-12111.

7. Miles L. A., Hawley S. B., Baik N., Andronicos N. M., Castellino F. J., Parmer R. J. Plasminogen receptors: the sine qua non of cell surface plasminogen activation. Front. Biosci. 2005;10:1754-1762.

8. Bonnefoy A., Moura R., Hoylaerts M. F. The evolving role of thrombospondin-1 in hemostasis and vascular biology. Cell. Mol. Life Sci. 2008;65(5):713-727.

9. Preissner K. T. Specific binding of plasminogen to vitronectin. Evidence for a modulatory role of vitronectin on fibrin(ogen)-induced plasmin formation by tissue plasminogen activator. Biochem. Biophys. Res. Commun. 1990;168(3):966-971.

10. Roka-Moya Y. M., Zhernossekov D. D., Grinenko T. V. Plasminogen/plasmin influence on platelet aggregation. Biopolym. Cells. 2012;28(5):352-356.

11. Deutsch D. G., Mertz E. T. Plasminogen: purification from human plama by affinity chromatography. Science. 1970;170(3962):10951096.

12. Panium S., Chalkey R. High resolution acrilamide gel electrophoresis of histones. Arch. Biochem. Biophys. 1969;130(1-2):337-346.

13. Sottrup-Jensen L., Claeys H., Zajdel M., Petersen T. E., Magnusson S. The primary structure of human plasminogen: isolation of two lysine-binding fragment and one "miniplasminogen" (M.W. 38000) by elastase catalyzed specific limited proteolysis. In: Progress in chemical fibrinolysis and thrombolysis (V. F. Davidson, Rowan R. H., Samama M. M., Desnoyers D. C. Raven Press, New-York.). 1977;3:191-209.

14. Novokhatny V. V., Kudinov S. A., Privalov P. L. Domains in human plasminogen. J. Mol. Biol. 1984;179(2):215-232.

15. Thewes T., Ramesh V., Simplaceanu E. L., Llinas M. Isolation, purification and $1 \mathrm{H}-\mathrm{NMR}$ characterization of a kringle 5 domain fragment from human plasminogen. Biochim. Biophys. Acta. 1987;912(2):254-269.

16. Gilting G., Bayer E. A., Wilchek M. Studies on the biotin-binding site of avidin. Biochem. J. 1987;242(3):923-926.

17. Miles L. A., Ginsberg M. H., White J. G., Plow E. F. Plasminogen interacts with human platelets through two distinct mechanisms. J. Clin. Invest. 1986;77(6):2001-2009.

18. Roka-Moya Y. M., Bilous V. L., Zhernossekov D. D., Grinenko T. V. Novel aspects of platelet aggregation. Biopolym. Cell. 2014;30(1):10-15.

19. Chung J., Wang X. Q., Lindberg F. P., Frazier W. A. Thrombospondin-1 acts via IAP/CD47 to synergize with collagen in alpha2beta1-mediated platelet activation. Blood. 1999;94(2):642-648.

20. Bonnefoy A., Hantgan R., Legrand C., Frojmovic M. M. A model of platelet aggregation involving multiple interactions of thrombospondin-1, fibrinogen, and GP IIbIIIa receptor. J. Biol. Chem. 2001;276(8):5605-5612.

21. De Poli P., Bacon-Baguley T., KendraFranczak S., Cederholm M. T., Walz D. A. Thrombospondin interaction with plasminogen. Evidence for binding to a specific region of the kringle structure of plasminogen. Blood. 1989;73(4):976-982.

22. George J. N., Lyons R. M., Morgan R. K. Membrane changes associated with platelet activation. Exposure of actin on the platelet surface after thrombin-induced secretion. J. Clin. Invest. 1980;66(1):1-9.

23. Wang H., Doll J. A., Jiang K., Cundiff D. L., Czarnecki J. S., Wilson M., Ridge K. M., Soff G. A. Differential binding of plasminogen, plasmin, and angiostatin 4.5 to cell surface beta-actin: implications for cancer-mediated angiogenesis. Cancer Res. 2006;66(14):72117215.

24. Lucas M. A., Fretto L. J., McKee P. A. The binding of human plasminogen to fibrin and fibrinogen. J. Biol. Chem. 1983;258(7):42494256.

25. Lishko V. K., Yermolenko I. S., Podolnikova N. P., Ugarova T. P. A novel mechanism controlling the growth of hemostatic thrombi. Ukr. Biokhim. Zhurn. 2013;85(6):94-105.

26. Miles L. A., Dahlberg C. M., Plow E. F. The cell-binding domains of plasminogen 
and their function in plasma. J. Biol. Chem. 1988;263(24):11928-11934.

27. Philippeaux M. M., Vesin C., TacechiniCottier F., Piguet P. F. Activated human platelets express beta 2 integrin. Eur. J. Haemotol. 1996;56(3):130-137.
28. Chavakis T., Athanasopoulos A., Rhee J. S., Orlova V., Schmidt-Wöll T., Bierhaus A., May A. E., Celik I., Nawroth P., Preissner K. Angiostatin is a novel anti-inflammatory factor by inhibiting leucocyte recruitment. Blood. 2005;105(3):1036-1043.

Received 17.03.2014 